\title{
Aspects of recent developments in the Latin American and Caribbean labour markets
}

\author{
Jürgen Weller
}

ABSTRACT

This article presents three stylized facts that characterized the evolution of labour markets

in Latin America and the Caribbean in the period 2003-2012 and represented breaks from previous trends. It is argued that these changes have to do with the economic and production context and the political and institutional framework. We show how the magnitude and patterns of economic growth impact on the nature of job creation, especially on shifts within and between economic sectors and the various segments of different productivity levels. We emphasize how changes in labour institutions have contributed to the evolution of labour indicators and, lastly, look at recent advances and persistent weaknesses in labour performance, as well as a number of risks to the continuity of recent favourable labour trends. 


\section{I}

\section{Introduction}

In the first decade of the 2000s, labour performance diverged markedly from the previous two decades in Latin America and the Caribbean. Especially from 2003 onwards, there was a break from several previous trends: the unemployment rate came down, many employment quality indicators improved amid increasing job formalization, and wage gaps between skilled and unskilled workers narrowed. These factors helped to reduce poverty rates and inequality between households in this period.

This favourable picture may be attributed in part to a number of factors that weighed in to one extent or another in the countries of the region, especially economic and production factors and political-institutional developments.

The analysis in this article centres on the 10-year period beginning in 2003, looking at how a more benign economic and production setting affected the labour markets. By contrast with the two preceding decades, in this period the region's economy enjoyed relatively sustained, high growth rates, interrupted only by the economic and financial crisis of 2008-2009. ${ }^{1}$ At the same time, many countries moved away from the growth and development paradigm that prevailed in the region in the 1980s and 1990s (reliance on the superior efficacy and efficiency of the functioning of markets), which implied, in many cases, adopting new labour policies. As this article will discuss, both factors had major consequences for labour market performance in this period.

The sections following this introduction review recent changes in the region's labour markets and interpret them against the backdrop of the changes

\footnotetext{
${ }^{1}$ See ECLAC (several years) and, specifically for the subperiod 2003 2008, Kacef and López-Monti (2010).
}

in the economic-industrial and political-institutional setting. Section II sets forth some stylized facts with regard to labour in the recent period, and contrasts them with previous performance. Section III presents a scheme developed to analyse the factors determining these changes, justifying the emphasis on the economicindustrial and political-institutional context. Section IV examines the characteristics of these factors in the decade 2003-2012, furthering understanding of recent developments in the labour market. Here, we show that the relatively high economic growth in recent times was the main factor driving job creation and bringing down the regional unemployment rate. A modest rise in labour productivity, thanks to several processes, facilitated gains in employment quality, as did strong labour demand, which led to many of the new jobs being created in medium- and high-productivity segments and shifted the structure of employment favourably. Patterns of labour demand also helped to reduce income gaps between people at different levels of employment. Lastly, a shift in labour institutionality in many countries also helped to close gaps and drove gains in employment quality. Section $\mathrm{V}$ concludes by discussing recent progress and persistent weaknesses in labour performance, and draws attention to a number of factors that pose risks to the continuity of recent benign labour trends. ${ }^{2}$

\footnotetext{
2 This article does not attempt to analyse all aspects of the recent labour market. The review of stylized facts concentrates instead on aspects that show a break in trend from previous performance, and skips over indicators that remained the same. This refers, for example, to the characteristics of labour supply, in which demographic trends held steady, labour participation continued to rise gradually and level of formal education continued to increase. Obviously, these stylized facts are not applicable to all the countries of the region, since they each have specific patterns regarding the determinants of labour performance.
} 


\section{II}

\section{Three stylized facts}

The first stylized fact regarding the development of labour markets over the recent period is the reduction in the open unemployment rate in urban areas. Between 2002 and 2012 this rate came down from $11.2 \%$ to $6.4 \%$ at the regional level, to reach a 20 -year low (ECLAC/ILO, 2013). ${ }^{3}$ This was a break from the general upward trend in unemployment in the 1990s, when the rate fell slightly in times of high economic growth and rose significantly in times of zero or slack growth, producing an upwardsloping jagged pattern in the regional unemployment rate. ${ }^{4}$

\footnotetext{
${ }^{3}$ The rate thus returned to the levels of the 1970s and 1980s. However, a precise comparison is not possible because of methodological changes made in many countries in the intervening period.

${ }^{4}$ In a study on 19 Latin American countries for the period 1990-2007 —although with differences depending on data availability — Ball, De Roux and Hofstetter (2011) found evidence of a hysteresis effect that transformed short-term rises in unemployment (caused by contractions in aggregate demand) into long-term impacts.
}

The fall in unemployment starting in 2003 resulted from a rapidly rising employment rate, as shown in figure 1.

While the participation rate reflected the long-term gradual increase in women's participation in the labour market, the employment rate rose sharply as of 2003, interrupted only in 2009 by the global economic and financial crisis.

Starting in 2003, the faster rise in employment, together with higher wages for those in work, pushed up labour income, which was the main driver of poverty reduction in the region in this period (ECLAC, 2012, p. 50; Azevedo and others, 2013).

The second stylized fact is the improvement in employment quality. As noted in Weller and Roethlisberger (2011), over the recent period almost all quality indicators show improvements, except for a rise in temporary contracts, which was attributable to more

FIGURE 1

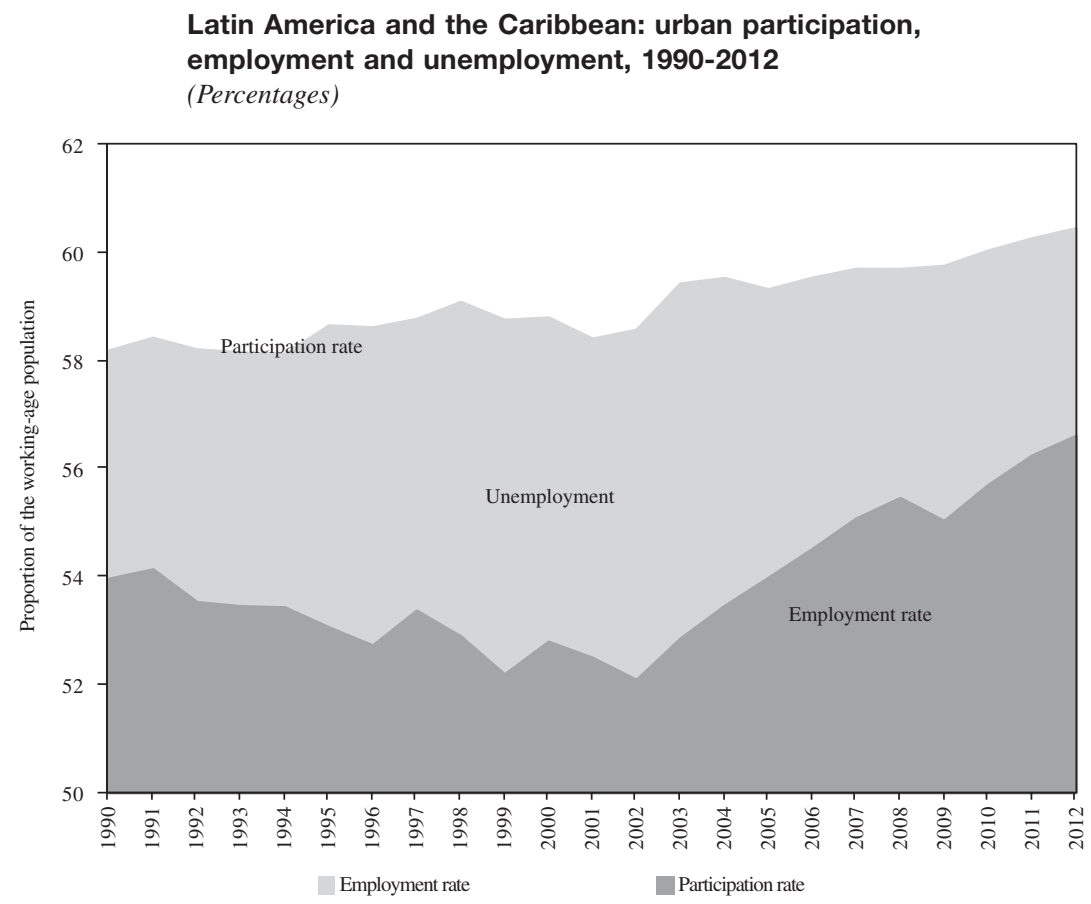

Source: prepared by the author, on the basis of official data from the countries.

Note: in the figure unemployment is shown as the gap between the participation and employment rates, so the values do not correspond to the unemployment rate, which is calculated as a proportion of the workforce. 
unstable labour markets. Quality indicators tend to be better for wage earners than for non-wage earners, but in the recent period employment quality has in general improved for both categories. ${ }^{5}$

As noted in the work cited above, these improvements are closely linked to processes of labour formalization which have made great strides in some countries. As shown in figure 2, in the decade 2003-2012 formal employment expanded more than in the preceding period, and notably more than employment overall, in many of the region's countries.

The third stylized fact is the reduction in wage gaps, in a break from the previous trends of wage structure polarization. ${ }^{6}$ In most of the countries, the reduction in

\footnotetext{
${ }^{5}$ See information on coverage differentiated by type of social protection system and changes in this regard in ILO (several years).

${ }^{6}$ On wage gap narrowing, see, for example, Gasparini and others (2011); López-Calva and Lustig (2010); and Keifman and Maurizio (2012).
}

the wage gap was the main driver of reduction in income inequality at the household level in the past decade. For an average of 15 countries, around two thirds of the reduction came from smaller differences in income per employed person (ECLAC, 2012, p. 56). ${ }^{7}$ The second important factor was non-labour income, with the introduction and expansion of programmes targeting the poorest households. By contrast, demographic changes in the great majority of the countries (a smaller gap between the dependency rates of the first and fifth quintiles) contributed very little to the lessening of inequality. On average, the contribution of higher employment rates -which had a positive impact on poverty reductionhad even a slightly negative effect on equality because the proportion of employed adults rose at least as much or more in the higher income quintiles as in the lowest.

\footnotetext{
${ }^{7}$ In this connection, see also Azevedo, Inchauste and Sanfelice (2013).
}

FIGURE 2

\section{Latin America (selected countries): annual growth in (registered) formal employment and total employment, 1990-2002 and 2003-2012 (Percentages)}

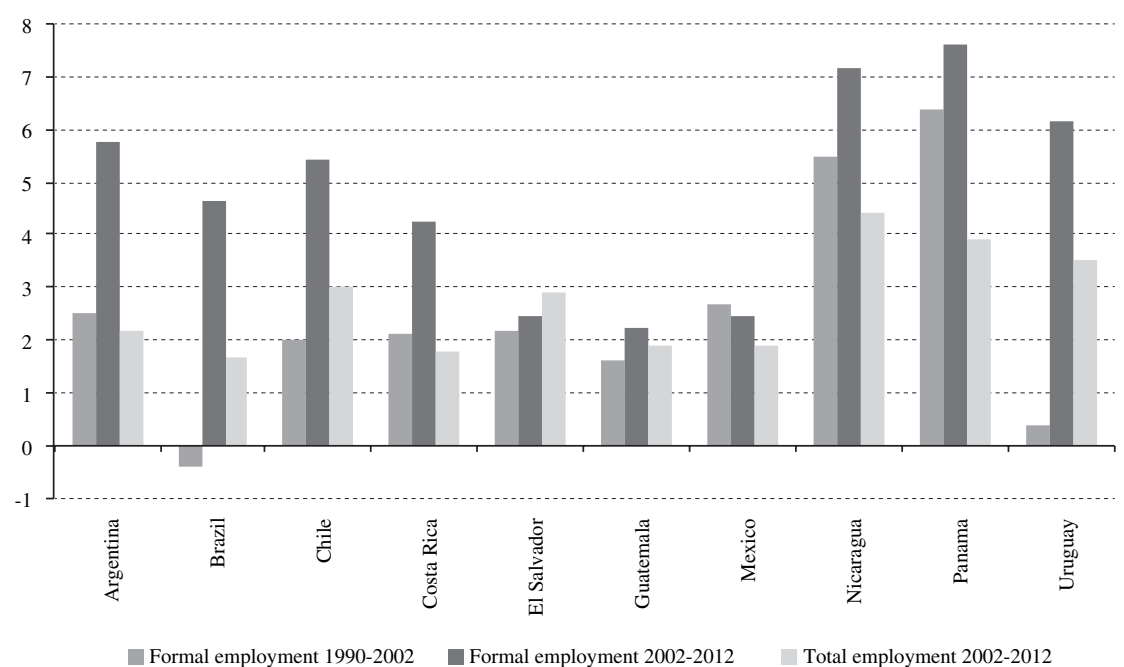

Source: prepared by the author, on the basis of official data from the countries.

Note: the data on formal employment refer to those paying into or affiliated to a system of contributory social protection, except in Brazil (register of formal employment). The data on total employment for Argentina and Uruguay refer to urban employment. The data on total employment for Guatemala and Nicaragua refer to 2002-2011 and 2003-2010, respectively. In the first period, the data on formal employment refer to 1991-2002 for Panama; 1994-2002 for Chile, Mexico and Nicaragua; 1995-2002 for Argentina, and 1998-2002 for El Salvador. 


\section{III}

\section{Conceptual aspects}

The main determinants of employment generation and job characteristics are the economic and production context and labour institutions. ${ }^{8}$ Figure 3 summarizes the main links in this regard.

The production context is expressed, first, in economic growth based largely on greater use of production factors, including labour. Growth impacts not only the magnitude of employment generation, but also - through its characteristics (sectoral composition, technical intensity, and so forth) - labour demand, differentiated by skills, knowledge, etc., and therefore influences the relative labour conditions of different groups of workers.

Second, and obviously related to the first aspect, the economic and production context is also expressed in

\footnotetext{
${ }^{8}$ Here, we are leaving aside the close long-term correlation between employment level and demographic evolution (magnitude and growth of the working-age population), modified by the upward trend in labour participation caused by the increasing incorporation of women into the labour market. In this connection, see Weller and Kaldewei (2013, pp. 31 and 32).
}

an economy's average labour productivity. This affects the capacity to improve job quality, because it is a determinant of the profit margin allocated to workers. In this respect, the main link is between labour productivity and wage level. The comparison between countries shows that this link tends to be a close one, although labour productivity gains do not translate automatically into wage gains, as demonstrated by the recent worsening of functional income distribution. ${ }^{9}$ But non-wage aspects of employment quality tend to benefit from increased productivity too, inasmuch as the various aspects of quality tend to generate costs, and the capacity of economies to cover those costs depends on the resources available. Accordingly, high productivity tends to feed directly into good quality employment, while low productivity usually

\footnotetext{
9 ECLAC/ILO (2012) shows both the high correlation between labour productivity and average wages, and the recent fall in wages as a proportion of GDP.
}

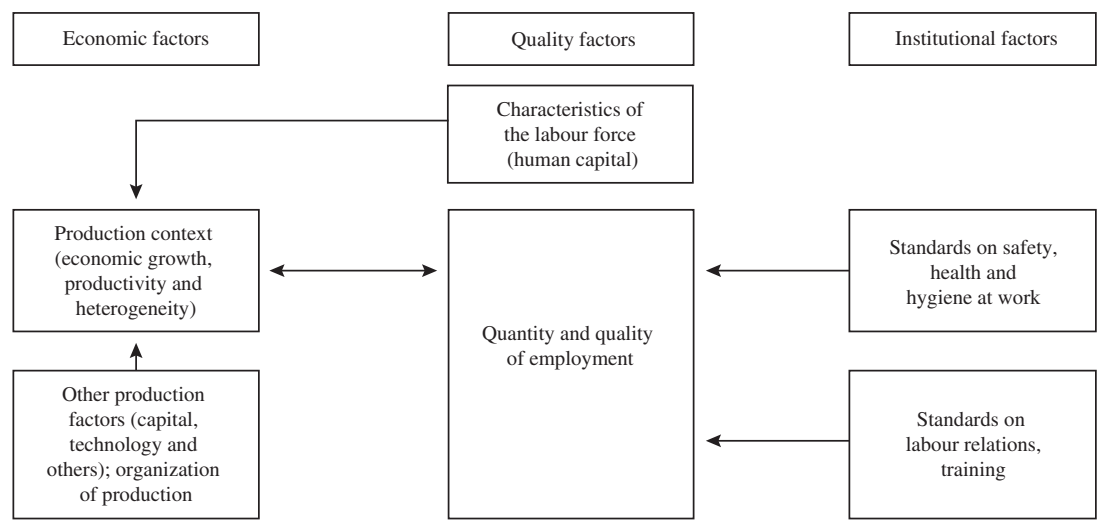

Source: prepared by the author, on the basis of Jürgen Weller and Claudia Roethlisberger, "La calidad del empleo en América Latina", Macroeconomía del Desarrollo series, No. 110 (LC/L.3320-P), Santiago, Chile, Economic Commission for Latin America and the Caribbean (ECLAC), 2011. United Nations publication, Sales No. S.11.II.G.39. 
goes hand in hand with processes of exclusion from productive employment. ${ }^{10}$

Rising labour productivity at the aggregate level reflects two different, but related, dynamics. On the one hand, economic development is closely related to structural change processes that involve reassigning resources from low-productivity sectors — which typically create low quality jobs- to intermediate- and high-productivity sectors (productivity gain through intersectoral changes). On the other hand, productivity with an activity can be boosted by more intensive use of physical or human capital or both, by technological changes, by more efficient use of resources, or by the closure of unproductive firms and the formation of new firms that are more productive (productivity gain through intrasectoral changes). The relative weight of the two processes typically varies with the march of economic development, with the contribution of structural change gradually diminishing (Rodrik, 2013).

However, and in third place, in highly heterogeneous production structures, the importance of the production context in generating and informal employment cannot be captured by the rate of economic growth and the evolution of average productivity alone.

The segmentation hypothesis is often refuted by the argument that a significant proportion of employment informal is voluntary and arises from cost-benefit calculations on the part of firms and workers. Specifically, it is possible to tap into the social benefits that are also increasingly accessible for informal employees, without having to assume formalization-related costs. Studies on flows of workers within this market also indicate a degree of mobility between the different segments, which appears to contradict the theory of segmented markets (Perry and others, 2007; Bosch, Cobacho and Pagés, 2012). Without denying the role of cost-benefit rationale

\footnotetext{
${ }^{10}$ Weller and Roethlisberger (2011, pp. 54-58) show some correlations between per capita GDP (as an indirect variable for labour productivity) and several indicators of employment quality. The most obvious positive links occurred between payment into social security systems (pensions and health), contracts and, to a lesser extent, bonuses and vacation. Other indicators (trade union membership, overtime pay, training) showed high dispersion, which points to the importance of other factors beyond per capita GDP and, related to that, average productivity, specifically the importance of labour institutions, which will be examined later. Notably, the link between labour productivity and employment quality is two-directional, as has been observed historically, for example with the shortening of the working day. Efficiency wage theory examines the impact of better wages on higher productivity. In this regard, see Akerlof and Yellen (1986).
}

of both formality and informality, it must be emphasized that there are theoretical and empirical reasons to treat markets as segmented (Fields, 2004; Ocampo, Rada and Taylor, 2009; Infante, 2011):

- The region's production structure is highly heterogeneous, with large productivity gaps between and within sectors.

- Because of weak labour demand in medium- and high-productivity segments and the jobs that are created mainly in response to this demand, other jobs are created mainly in response to the pressure of labour supply, reflecting the need for income in the respective households. ${ }^{11}$

In any case, the different approaches in the literature on labour market segmentation have made progress in recognizing the heterogeneous nature of the informal sector itself. ${ }^{12}$ While certain approaches differentiate between "excluded" and "voluntary" informal workers, from the standpoint of production, a subsegment with a certain capacity of accumulation is distinguished from one whose income is basically stuck at subsistence level. Accordingly, there would appear to be a countercyclical subsegment - which grows in phases of the economic cycle in which the labour demand from the medium- and high-productivity segments is low- and another that behaves procyclically, expanding in response to income opportunities in growing economies.

In addition, the simultaneous existence of different labour market segments —whose behaviour is determined chiefly by labour supply and demand, respectively — is evident in the way labour adjusts to the economic cycle. Specifically, the fact that a large segment of the labour market obeys labour supply dynamics contributes much to the highly procyclical behaviour of labour productivity (ECLAC/ILO, 2012).

In sum, the level and composition of informality depend on two main factors: the production structure -represented by per capita GDP and the productivity gaps between the different segments - and the legal and

\footnotetext{
11 In this article "segment" means the set of those parts of different branches of activity or sectors that share similar productivity levels, drawing a simplified distinction between low-productivity segments and medium- and high-productivity segments. The shift in the relative importance of the two segments over the business cycle is recognized by Perry and others (2007).

12 See, for example, Tokman (1987); Fields (2004) and Perry and others (2007).
} 
institutional factors that determine the costs and benefits of both formality and informality. 13

The existence of segmented markets with large productivity gaps means that changes in the composition of occupational structure - especially in the relative weight of the lower- or higher-productivity segmentsinfluences its overall averages as well as labour income. Labour market segmentation has distributive implications as well. Although the theories disagree as to whether low-productivity segments should be modelled with marginal output close to zero or positive, declining output (Fields, 2004), an increase in the number of individuals employed in these segments will tend to lower average income and widen the income gap with respect to the higher-productivity segments. By contrast, a reduction in the number of individuals in these poor performing segments will increase average income and narrow the gap with respect to the average or higherproductivity segments. One implication of this is that the income gap between different productivity levels will be wider in countries with a larger set of lowproductivity segments than in countries with a smaller set of such segments: in the first group of countries, low-productivity segments tend to show smaller average income, owing to the larger proportion of jobs generated by supply pressure, thereby increasing the gap between this income level and the income of medium- and high-productivity segments. ${ }^{14}$

Lastly, labour institutions — based on labour legislation or on collective bargaining - shape the characteristics of employment, particularly matters of quality and the gaps between different groups of workers

\footnotetext{
13 There are also secondary aspects, such as the lack of information on these costs and benefits for informal firms and workers.

14 Weller (2012, p. 35) demonstrates this for Latin America.
}

in this regard (for example, through formalization or minimum wage policies). Labour institutions have a dual function (ECLAC, 2010, p. 173): (i) contribute to the efficient functioning of the labour market (by bringing the workforce increasingly into productive jobs), boost productivity (including the effective distribution of the fruits thereof) and design mechanisms to adjust to the fluctuations of the economic cycle; and (ii) promote the protection of workers as the structurally weakest stakeholders, especially vulnerable groups with specific problems in participating in productive labour.

To this end, labour legislation and collective bargaining affect the process of establishing wages and other benefits, contracts, social protection, and training, among other aspects. In turn, standards on hygiene and safety at work and on the organization of work (pace, breaks and so on) affect labour conditions.

On the other hand, the capacity of firms to comply, the coverage and efficiency of labour surveillance and labour justice, and the control and pressure that workers can exert determine the degree to which the quality aspects covered in the legislation or negotiations come to fruition (Bensusán, 2008).

Institutions can only meet their objectives in a sustainable manner if they are positioned on two fronts (Berg and Kucera, 2008, p. 27): first, they reflect the social norms created historically in a specific country, so they vary from one country to another. It is thus no surprise that the theoretical literature is increasingly considering the possibility of moving from models that assume a single optimum configuration of regulations, to others that allow for the existence of two or more institutional configurations capable of generating similar outcomes (Eichhorst, Feil and Braun, 2008). Second, they respond to the production context, so that in any given country they can vary over time in response to social and political changes. 


\section{IV \\ Changes in the determining factors and in their links with the stylized facts}

This section explores how changes in the economic and production context and in labour institutions may have impacted the stylized facts described in section II during the period beginning in 2003 .

\section{The economic and production structure}

\section{(a) Economic growth and overall employment}

The growth and characteristics of employment were the main factor explaining the rise in employment levels, and thus the declining unemployment rate. In the period beginning in 2003, the Latin American and Caribbean economies evolved very differently from the preceding decades. New global growth patterns and buoyancy pushed up prices for the region's main export commodities, which improved terms of trade to the benefit of countries exporting oil, gas, minerals and agricultural products. ${ }^{15}$ This was a key factor in boosting the region's economic growth above the performance of previous decades. Economic authorities used the opportunity offered by this context to reduce vulnerabilities, lower public debt (especially external debt), and build up international reserves. The combination of brighter growth prospects and reduced vulnerabilities helped to improve external borrowing conditions, especially amid highly liquid global markets (ECLAC, several years).

The region's economic growth rose from $2.7 \%$ per year between 1990 and 2002 to 3.8\% per year from 2003 to 2012, despite the harsh impact of the global economic and financial crisis in 2008-2009. ${ }^{16}$ Growth patterns have varied throughout the past decade, since in 2003-2008 exports increased rapidly (from $16.9 \%$ of GDP on average in $1990-2002$ to $22.7 \%$ on average in 2003-2008, at constant prices). By contrast, in 2009-2012 household consumption and gross fixed capital formation were the main drivers of aggregate demand (with average rises from $63.0 \%$ in $2003-2008$ to $65.0 \%$ in $2009-2012$ for household consumption and from $19.1 \%$ to $21.2 \%$ for

\footnotetext{
15 Differences in the composition of the export and import baskets were obviously reflected in very varied terms of trade evolutions in the different countries of the region.

16 The region grew by $4.5 \%$ per year between 2003 and 2008, 4.4\% per year between 2010 and 2012, and contracted by $1.6 \%$ in 2009 .
}

gross fixed capital formation). ${ }^{17}$ By sector, growth was concentrated in the various branches of the tertiary sector, and this pattern deepened between 2009 and 2012. ${ }^{18}$

As shown in figure 4, the rise in the employment rate noted earlier (see figure 1) is attributable in large measure to these higher rates of economic growth.

With the exception of 2009, in all the years between 2003 and 2012 the urban employment rate rose by 0.4 percentage points or more.

The correlation between economic growth and employment rate variation indicates, as well, an increase in the labour intensity of growth. The data in figure 4 show that in the 1990s, economic growth of $3 \%$ at the regional level was accompanied by a drop in the regional urban employment rate of 0.1 percentage point, while in the period beginning in 2003 this same output growth rate was accompanied by a rise of over 0.3 point in the employment rate (ECLAC, 2014b). The low labour intensity of growth in the 1990s has been associated, among other causes, with the structural reforms of the time (Weller, 2000; IDB, 2003). This effect could have eased later, and in the following period there were few large-scale liberalizing reforms (ECLAC, 2014b). Be this as it may, the low labour intensity of growth at the regional level in the 1990s chiefly reflected the performance of a few countries (Argentina and Brazil), and in most of the countries of the region "jobless growth" was not the rule; most of them were rather characterized at this time by "employment without growth" (Pagés, Pierre and Scarpetta, 2009), reflecting the supply side pressure of labour in the context of low and volatile economic growth.

In sum, by comparison with the previous period, in the decade 2003-2012 the employment rate was significantly boosted by higher economic growth and stronger intensity of the labour factor in the process. Since the increase in the participation rate did not diverge from its long-term trend, the more robust job

\footnotetext{
17 Author's calculation on the basis of data from the Economic Commission for Latin America and the Caribbean (ECLAC).

18 Together, these branches of activity increased their share in GDP from $54.5 \%$ on average for $1990-2002$ to $55.3 \%$ for $2003-2008$, and $56.8 \%$ for $2009-2012$.
} 


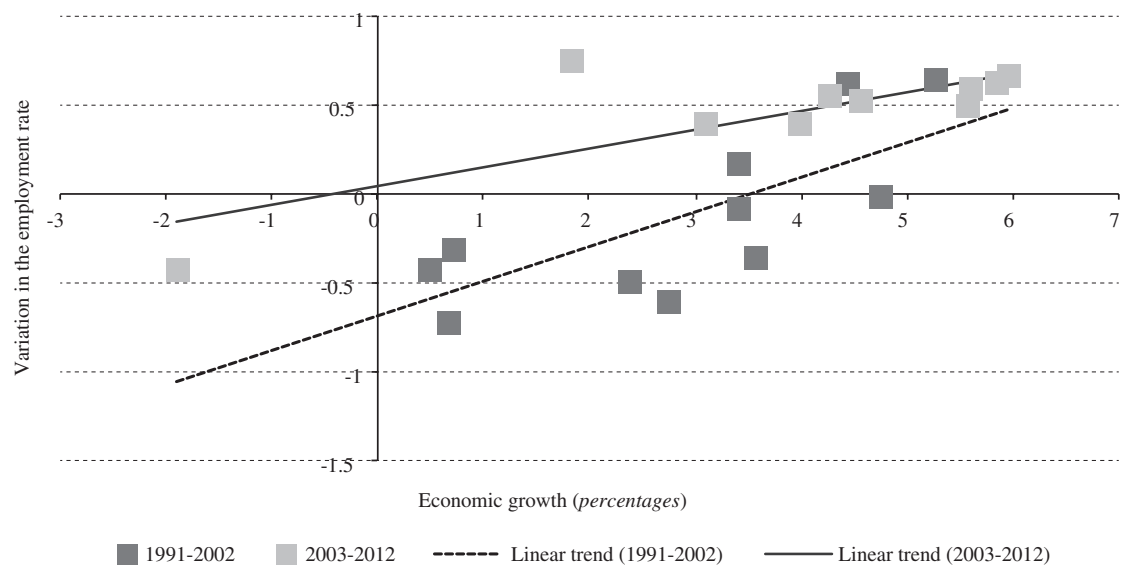

Source: prepared by the author, on the basis of data from the Economic Commission for Latin America and the Caribbean (ECLAC).

creation translated directly into a notable fall in the unemployment rate.

\section{(b) Changes in labour productivity}

Labour productivity evolution is a key determinant of improvement in both wage and non-wage aspects of employment quality. In 2003-2012, the more benign economic environment led to a rise in average labour productivity, which had fallen in the 1980s and stood still in the 1990s (Weller and Kaldewei, 2013). ${ }^{19}$

As noted earlier, this increase could have come from changes within economic sectors, or from the reallocation of resources - specifically the workforce- between sectors (structural change). For the 1980s, ECLAC (2007) found a sharp fall in average labour productivity, caused by intrasectoral effects with slightly positive intersectoral effects, while for 1991-2003 it found -in the simple average for nine countries - a slight rise in average labour productivity, with small positive contributions from both components. By contrast, McMillan and Rodrik (2011) found a strong positive contribution from intrasectoral changes, partially offset by negative

19 However, the $1.6 \%$ rise in average labour productivity between 2002 and 2012 was modest by comparison with some other world regions. Owing chiefly to the rapid increase in productivity in East Asia, by 2012 the gap that the region had gained with respect to the world average, which expanded by $2.2 \%$ in this period, was almost closed (author's calculation on the basis of data from Key Indicators of the Labour Market (KILM), eighth edition (ILO, 2013)). intersectoral change, for the period 1990-2005, also in the average for nine countries. ${ }^{20}$

Table 1 shows the results of an exercise for the periods 1990-2002 and 2003-2011/2012, for which the methodology used by McMillan and Rodrik (2011) was applied to 23 countries of Latin America and the Caribbean, as follows:

$$
\Delta Y_{t}=\sum_{i=1}^{n} \Theta_{i, t-k} \Delta y_{i, t}+\sum_{i=1}^{n} y_{i, t} \Delta \Theta_{i, t}
$$

where $Y_{t}$ and $y_{i, t}$ represent the level of productivity for the economy overall and for sector i, respectively, while $\Theta_{i, t}$ is the share of sector i in employment. $\Delta$ represents the change in productivity or in the proportion of employment, as the case may be. The first term on the right is the sum of the variations in productivity of the different sectors, weighted by their share in employment at the start of the period under analysis. This term thus represents changes in productivity within sectors. The second term represents the contribution of structural change to total productivity variation, calculated as the sum of sectoral changes in share of total employment, weighted by the corresponding productivities. ${ }^{21}$

\footnotetext{
${ }^{20}$ For other recent studies that break down the evolution of labour productivity for different periods, see Ocampo, Rada and Taylor (2009) and Ros (2011).

21 Thus, if a sector loses share in the structure of employment to another sector with higher average productivity, aggregate productivity increases, and vice versa.
} 
TABLE 1

Latin America and the Caribbean: variation in average labour productivity and contributions of intra- and intersectoral changes, 1990-2002 and 2003-2011/2012

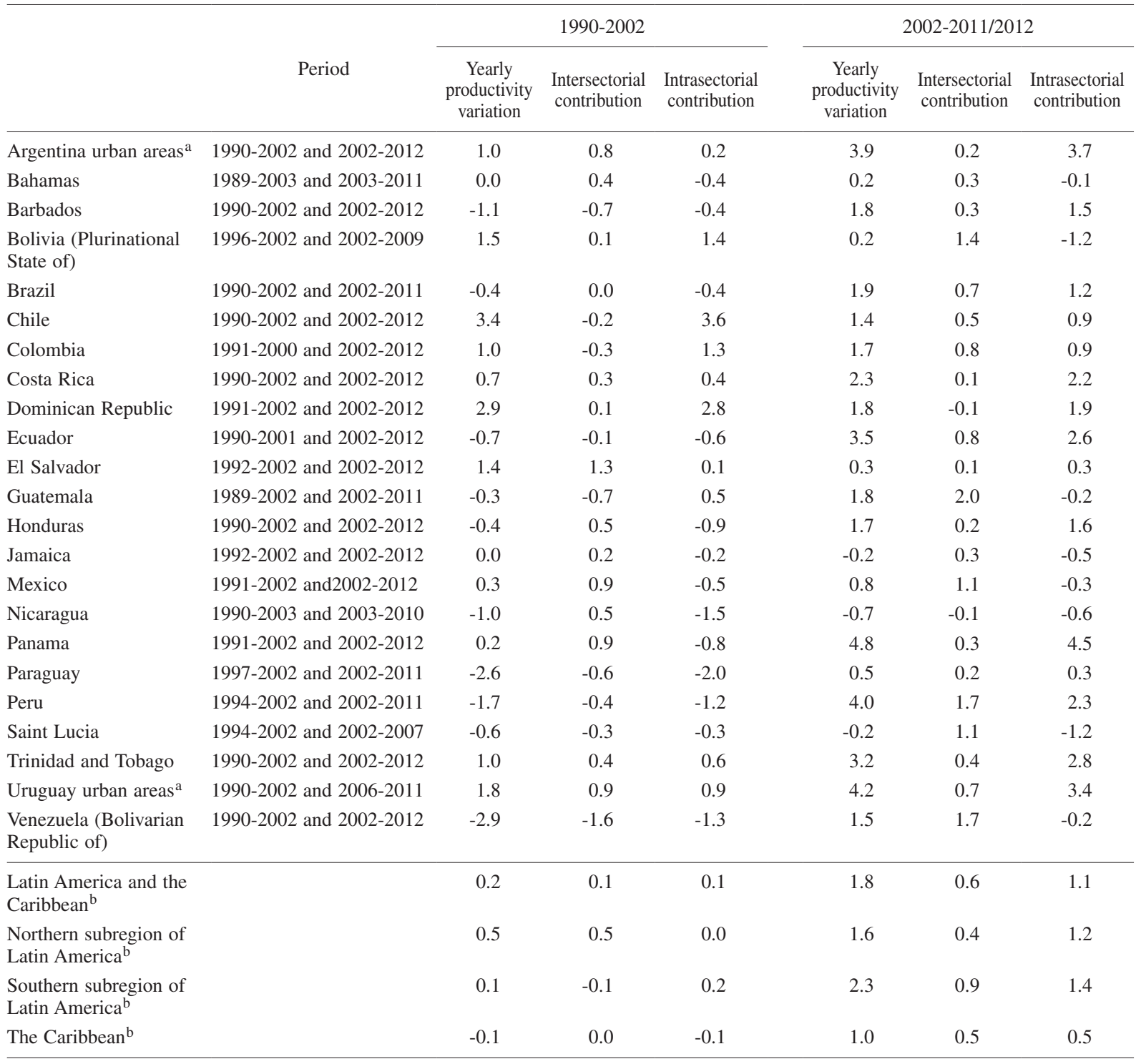

Source: prepared by the author, on the basis of Jürgen Weller and Cornelia Kaldewei, "Empleo, crecimiento sostenible e igualdad", serie Macroeconomía del Desarrollo, No. 145 (LC/L.3743), Santiago, Chile, Economic Commission for Latin America and the Caribbean (ECLAC), 2013; and official data from the countries and the Economic Commission for Latin America and the Caribbean (ECLAC).

a The data for Argentina (31 urban agglomerations) and Uruguay (for 1990-2002) (urban total) are indicative only, because information on non-agricultural output growth was combined with urban employment data, in the absence of nationwide employment figures.

b Simple average.

Note: rates of intra- and intersectoral contributions do not necessarily add up to the variation in productivity, because of rounding. The total refers to the sum of value added of the different branches of activity. The calculation was performed in dollars at constant 1995 prices for 1990-2002 and at constant 2005 prices for 2002-2011/2012.

The northern subregion corresponds to the countries from Mexico to Panama, plus the Dominican Republic; the southern subregion corresponds to the Latin American countries to the south of Panama. 
The result of this calculation shows the contribution of intrasectoral processes and structural change to variation in aggregate labour productivity, in constant dollar at 1995 prices for the first subperiod and at 2005 prices for the second. In order to compatibilize the results of the countries individually, and in view of the fact that the periods under analysis are of different length, annual growth rates of labour productivity were calculated for all countries and the contributions of intra- and intersectoral changes were translated into contributions to those growth rates.

Again, average labour productivity growth was faster in the second period, as compared with small rises in the first. In the regional average, between 1990 and 2002 neither intrasectoral changes nor structural change contributed to average labour productivity growth, whereas both made a positive contribution in the second period, with structural change representing about a third of aggregate labour productivity growth, and intrasectoral changes the other two thirds. There were large differences between countries and subregions in both periods, however. In the first period, intersectoral changes made a stronger contribution in the northern subregion, possibly because of the expansion of the maquila industry and mass emigration, especially to the United States. In the second period, the southern subregion showed better results in both components of productivity growth. In both periods, the Caribbean showed weaker results.

Slightly rising labour productivity helped bring about increases in real wages. According to household survey data, on average in the Latin American countries, average urban wages rose from 4.1 to 4.7 poverty lines per capita between 2002 and 2012, having risen from 3.8 to just 4.2 poverty lines per capita between 1990 and 2002 (ECLAC, 2013). However, real wages generally rose at lower rates than labour productivity, which points to the importance of the work of labour institutions, as well (ECLAC/ILO, 2012).

The evolution of labour productivity differentiated by branch of activity, resulting from intra- and intersectoral changes, also affected productivity gaps between these branches. As may be observed in table 2, in 1990-2002 productivity gaps broadened between branches of activity in the region (both in the weighted average of productivities, and in the simple average of productivities at the level of each economic activity), thereby deepening the region's hallmark structural heterogeneity. By contrast, in the following period the gaps narrowed by about the same amount as they had widened in the previous period, reflecting changes in the patterns of employment generation in segments with different productivity levels, as will be discussed in the following section.

TABLE 2

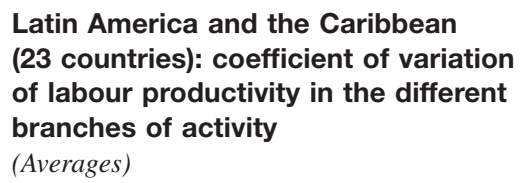

\begin{tabular}{lcc}
\hline & Weighted average & Simple average \\
\hline 1990 & 0.78 & 0.96 \\
2002 & 1.05 & 1.04 \\
2002 & 1.63 & 1.15 \\
$2010-2011$ & 1.36 & 1.08 \\
\hline
\end{tabular}

Source: Jürgen Weller and Cornelia Kaldewei, "Empleo, crecimiento sostenible e igualdad", Macroeconomía del Desarrollo series, No. 145 (LC/L.3743), Santiago, Chile, Economic Commission for Latin America and the Caribbean (ECLAC), 2013.

Note: the first two lines (1990 and 2002) are based on productivity calculations in dollars at constant 1995 prices; the following two (2002 and 2010-2011) are based on productivity calculations in dollars at constant 2005 prices. The column "Weighted average" refers to the coefficient of variation of productivity of the various branches in the weighted average for the countries.

In sum, in 2003-2012, process of intra- and intersectorial change generated modest rises (with significant differences between countries) in labour productivity. This supported gains in real wages and improvements in non-wage indicators of employment.

\section{(c) Economic growth and employment generation in the segments of production}

As proposed in section III, in heterogeneous labour markets it is not enough to review the impact of changes in aggregate indicators between and within branches of activity; it is also essential to look at changes occurring between and within segments of varying productivity levels. This section illustrates the importance of this second aspect. ${ }^{22}$

As shown in figure 5, in the 1990s urban employment generation was concentrated mainly in low-productivity segments, which - in the simple average for the countries with information available - increased their share of

\footnotetext{
22 Since the information available is not sufficient to measure the size of these segments regularly, labour indicators are used as a proxy. For some time now, ECLAC has been measuring the size of low-productivity segments in urban areas by the proportion of employed who are ownaccount workers (excluding professionals and technical workers), wage earners and employers in microenterprises, domestic service workers, or unpaid family workers.
} 
urban employment from $45.7 \%$ to $50.1 \%$. Starting around 2002, the proportion of employment in mediumand high- productivity segments rose in almost all the countries in the region, and fell in the low-productivity segments to around $44.1 \%$ on average.

Owing to data availability limitations, the analysis of the relationship between economic growth and the characteristics of employment generation looks at two categories of employment as proxies for labour segments driven by supply and demand, respectively: wage employment and own-account work. ${ }^{23}$

Figure 6 shows, for the region overall, a high positive correlation (0.86) between economic growth and wage

23 Although not all wage employment corresponds to the demanddriven segment, and not all own-account work to the supply-driven segment, as will be seen, the great majority of the first category shows demand-driven patterns, and most of the second, supply-driven patterns.

FIGURE 5

Latin America: proportion of the urban employed working in low-productivity segments, 1990-2002 and 2002-2012

(Percentages)
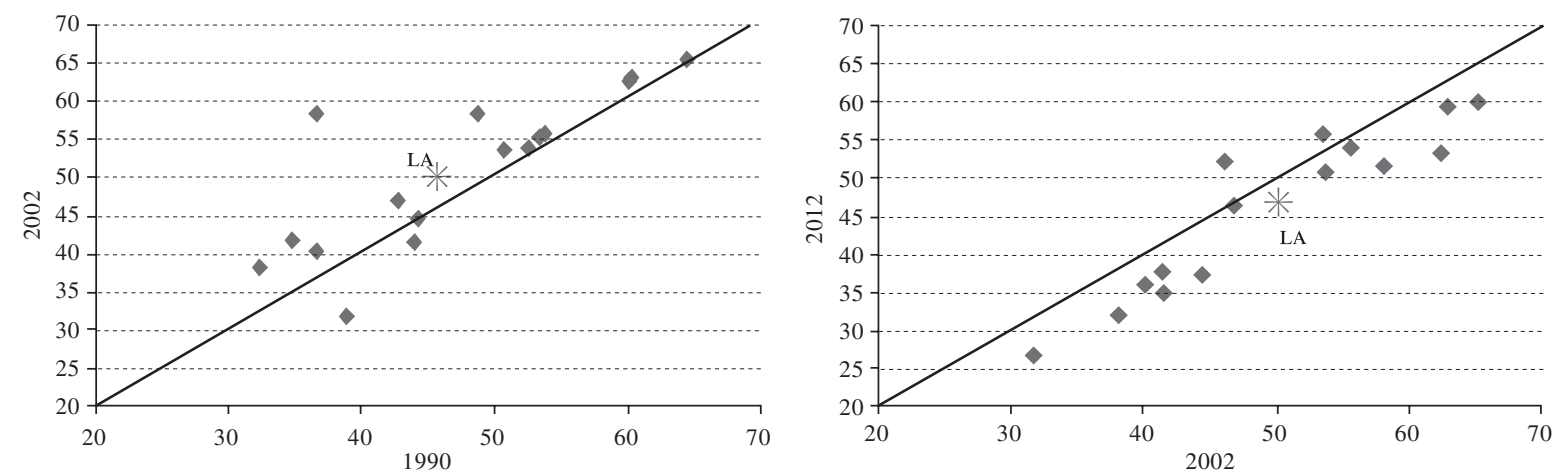

Source: Economic Commission for Latin America and the Caribbean (ECLAC), Social Panorama of Latin America, 2013 (LC/G.2580), Santiago, Chile, 2013. United Nations publication, Sales No. E.14.II.G.6.

LA: Latin America.

FIGURE 6

Latin America and the Caribbean: economic growth and changes in employment generation, 1995-2012

(Percentages)

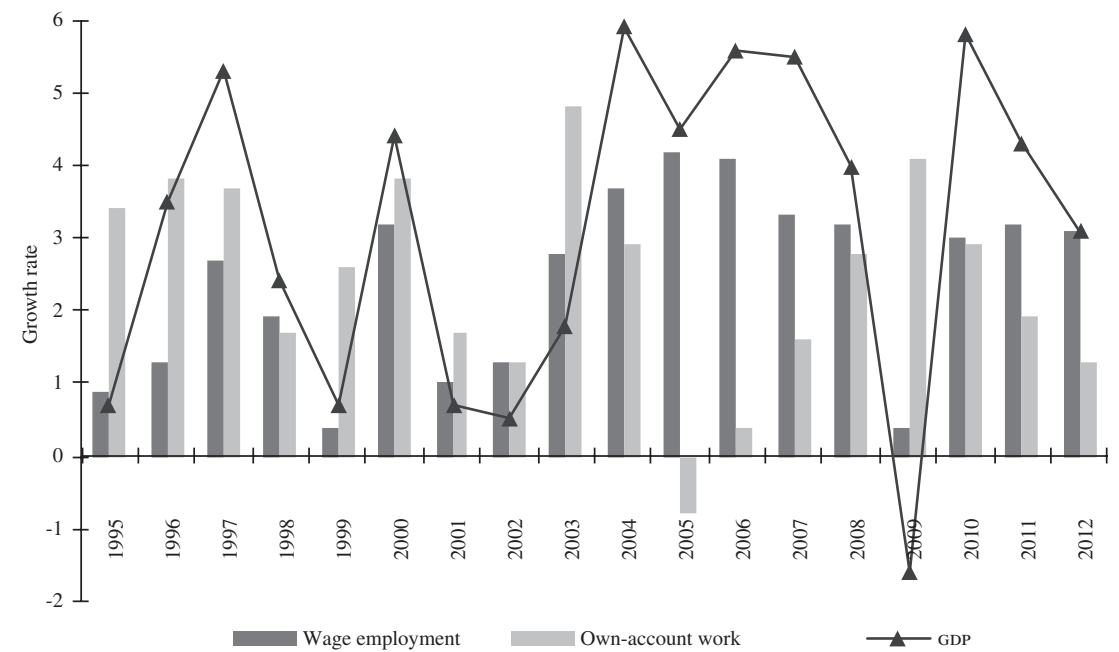

Source: prepared by the author, on the basis of official information from the countries and the Economic Commission for Latin America and the Caribbean (ECLAC).

GDP: gross domestic product. 
employment in 1995-2012, since wage employment rose notably in years of high economic growth and very little in slow-growth or crisis years.

There is, conversely, a much less clear-cut relationship between economic growth and own-account work. In several years, own-account work behaved countercylically, reflecting supply-side dynamics (for example in 1995, 1996, 1999 and 2009 in the context of weak wage employment generation, and between 2005 and 2007, in a relatively lengthy period of buoyant wage job creation). This behaviour reflects the nature of low-productivity segments, driven from the supply side by household need.

However, own-account work also behaves procyclically in some years, both amid relatively strong economic growth (1997, 2000, 2004, 2008 and 2010) —when not only was labour demand high, but individuals needing income found favourable opportunities for independent work - and amid low growth (2001 and 2002).

These varied dynamics underscore the internal heterogeneity of low-productivity segments, as mentioned in section III. Not only those excluded from wage employment enter own-account work; there is also a dynamic subsegment of opportunity-seekers. The overall result of the different rationales was that in 1995-2012 the correlation between GDP growth and the generation of own-account work at the regional level was -0.23 (in other words, the countercyclical factor prevailed).

These same results are found at the country level. As shown in table 3 , in the median for 14 countries wage employment has a correlation coefficient of 0.58 with economic growth, whereas the coefficient for ownaccount work is -0.27 . Albeit with large differences between countries, wage employment behaves clearly procyclically. By contrast, the presence of both procyclical and countercyclical dynamics in own-account work leads to quite low correlation coefficients; the negative sign in almost all the countries appears to indicate that the countercyclical pattern prevails, however.

Higher economic growth thus especially favoured wage employment generation, which contributed to labour formalization. Since the pattern of wage employment is closely correlated with economic growth, in the aggregate growth is a stronger determinant of total employment generation in countries with higher relative rates of wage employment $^{24}$ (Weller, 2012).

The output elasticity of wage employment was approximately 0.5 in the median for the group of countries in the period 1995-2012. Although with much variation between countries, the predominant pattern points to consistent efforts to increase productivity, which (in the

\footnotetext{
${ }^{24}$ Proportion of wage employment in total employment.
}

TABLE 3

Latin America (selected countries): employment-economic growth correlation coefficients and GDP elasticity of wage employment, 1995-2012

\begin{tabular}{|c|c|c|c|c|}
\hline & \multicolumn{3}{|c|}{ Employment-economic growth correlation coefficient } & \multirow{2}{*}{$\begin{array}{c}\text { GDP elasticity of } \\
\text { wage employment }\end{array}$} \\
\hline & Total employment & Wage employment & Own-account work & \\
\hline Argentina (17) & 0.71 & 0.77 & -0.07 & 0.56 \\
\hline Brazil (18) & 0.63 & 0.62 & 0.21 & 0.75 \\
\hline Chile (17) & 0.54 & 0.65 & -0.27 & 0.38 \\
\hline Colombia (18) & 0.15 & 0.53 & -0.34 & 0.26 \\
\hline Costa Rica (18) & 0.37 & 0.45 & -0.27 & 0.59 \\
\hline Ecuador (17) & -0.19 & -0.13 & -0.01 & 1.32 \\
\hline El Salvador (16) & 0.04 & 0.44 & -0.30 & 0.45 \\
\hline Honduras (14) & -0.31 & 0.20 & -0.03 & 0.91 \\
\hline Mexico (17) & 0.79 & 0.87 & -0.58 & 0.50 \\
\hline Panama (18) & 0.34 & 0.70 & -0.42 & 0.37 \\
\hline Peru (13) & 0.08 & 0.33 & -0.08 & 0.26 \\
\hline Uruguay (11) & 0.67 & 0.77 & -0.30 & 0.06 \\
\hline Latin America (median) & 0.42 & 0.58 & -0.27 & 0.52 \\
\hline
\end{tabular}

Source: prepared by the author, on the basis of official information from the countries and the Economic Commission for Latin America and the Caribbean (ECLAC).

Note: the figure in brackets is the number of years with information available in each country.

GDP: gross domestic product. 
aggregate) is partially offset by the expansion —albeit slowly more recently — in low-productivity jobs, reflecting persistent structural heterogeneity.

These changes in employment generation patterns helped to increase average labour income. Specifically, the concentration of new job creation in medium- or high-productivity segments led to a rise in average labour income, as shown in figure 7.

While in the 1990s the expansion of employment mainly in low-productivity segments had a slightly negative impact on average labour income, in the following period part of the rise in labour income was attributable to the reallocation of a portion of the workforce from low-productivity segments to mediumor high-productivity segments.

Since labour arrangements are much more formalized in the employment categories that make up the mediumand high-productivity segments, the shift in composition reflects improvements in formality levels and, thus, in employment quality. ${ }^{25}$

25 See Weller and Roethlisberger (2011) and ILO (several years). In addition, formalization policies targeting both sectors may have an impact (in this respect, see section IV.2.b).
The concentration of a large share of new jobs in the medium- and high-productivity segments, reflecting strong labour demand, was related to the expansion of formal employment in the tertiary sector, which in less favourable circumstances typically provides an informal and low-productivity refuge amid labour supply pressure (ECLAC, 2014b).

As figure 8 shows, in many countries commerce and services, and also construction, showed rates of formal employment growth well in excess of the rate in manufacturing and agriculture. This sectoral breakdown of formal employment reflects above all the pattern of economic growth increasingly focused on domesticdemand-related activities (those producing mainly non-tradable goods and services), which concentrated labour demand in those activities, thus facilitating the expansion of formal employment there.

The largest gaps between the expansion of total employment and formal employment occurred in the agricultural sector, mining, commerce, and community, social and personal services. This appears to be due to three factors: first, some of these sectors have low entry barriers, so that in low growth periods supply-driven employment creation is concentrated there, and this pattern

FIGURE 7

Latin America (median of 16 countries): breakdown of increases in labour income, by intra- and intersectoral contributions of segments of varying productivity levels, 1990-2002 and 2002-2011

(Per capita poverty line equivalents)

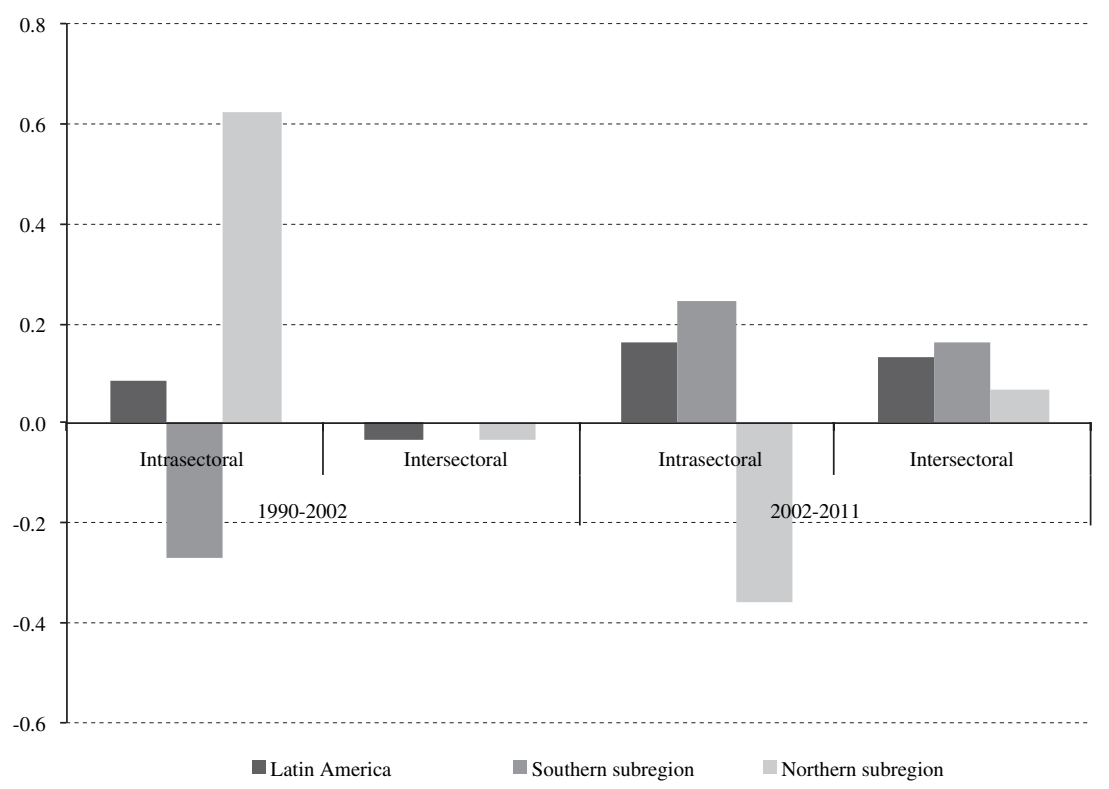

Source: prepared by the author, on the basis of Economic Commission for Latin America and the Caribbean (ECLAC), Social Panorama of Latin America, 2012 (LC/G.2557-P), Santiago, Chile, 2013. United Nations publication, Sales No. E.13.II.G.6. 

added by branch of activity, annual growth rates, 2002-2012

(Percentages)

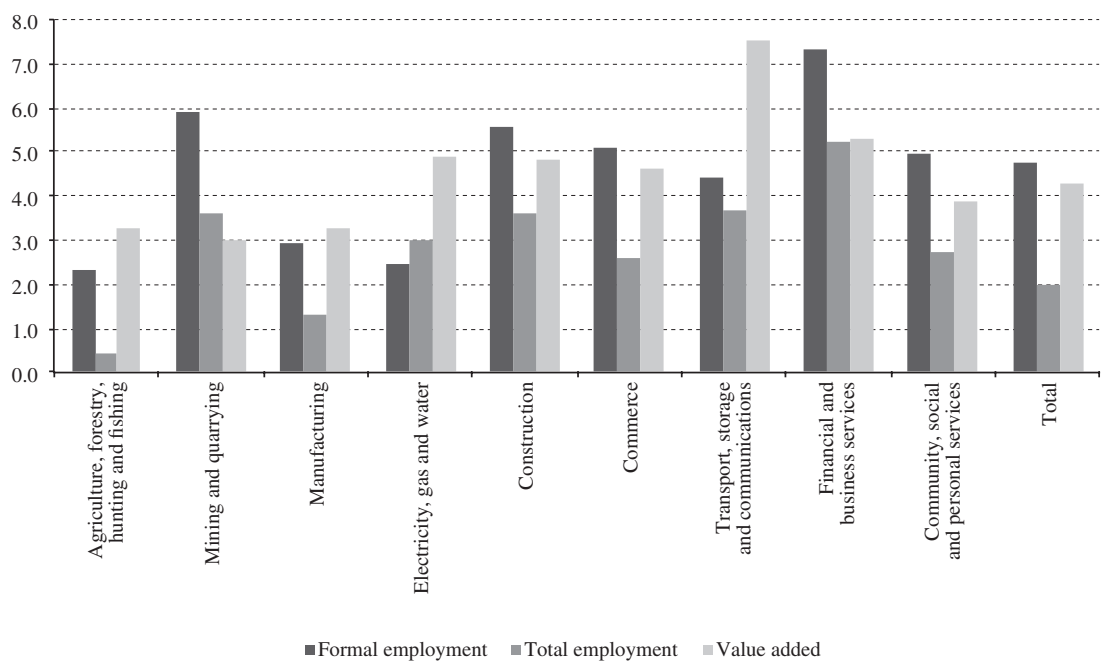

Source: prepared by the author, on the basis of official data from the countries.

Note: the information covers the following countries: Argentina, Brazil, Chile, Costa Rica, Ecuador, El Salvador, Guatemala, Mexico, Nicaragua, Panama and Peru. The data on formal employment refer to those paying into or affiliated to a contributory social protection system, except in Brazil (register of formal employment), Ecuador and Peru (surveys of firms with 10 or more workers in selected branches of activity). The data of annual growth in total employment and value added refer to the period 2002-2012, except in the cases of Brazil, Guatemala and Peru (2002-2011), Ecuador (2003-2012) and Nicaragua (2003-2010).

eases when economic growth is higher. Second, formal activities expanded strongly in some sectors, especially commerce, partly to the detriment of informal segments. And, third, efforts to formalize labour markets may have had a differentiated effect by sector, with greater progress in the abovementioned sectors.

In sum, the characteristics of labour demand have impacted the recomposition of employment, allowing advances in wage and non-wage aspects of work and improvements within branches of activity.

\section{(d) Growth, characteristics of labour demand and reduction of wage inequality \\ Did economic growth and its characteristics play a} role in the third of the stylized facts, the narrowing of the wage gap? As noted in section IV, the rise in the quantity of employment did not contribute directly to reducing inequality at the household level, but employment traits may have narrowed the gap in labour income, the most important mechanism in this regard. One key finding was that the rise in educational level appears to have helped to improve distribution by reducing gaps between household quintiles with different levels of per capita income (Cruces, García Domenech and Gasparini, 2012).
The labour policies applied during this period were another important factor (see section IV.2).

There are also signs that the skills bias in labour demand may have reversed during the first decade of the 2000s.

Among the causes of narrower income gaps, López-Calva and Lustig (2010) identify, for the four case studies they present on Argentina, Brazil, Mexico and Peru, decreasing demand bias for skilled workers, as the impact of intensive technological change on qualifications (triggered by the economic reforms of the 1980s and 1990s) runs its course.

Gasparini and others (2011) argue that demand for less skilled labour may have increased in the context of commodity expansion and intrasectoral processes, such as technology spread and the mismatch between the skills of workers with higher levels of formal education and the jobs available. The World Bank (2012) suggests that the concentration of growth in non-tradable sectors may have reduced the demand for higher-skilled workers, which is lower in these sectors than in manufacturing.

Table 4 shows the composition of additional employment for 15 countries, by level of education and differentiating wage employment (reflecting 
demand for labour on the part of firms) from non-wage employment (representing different dynamics, mainly supply-side pressure). ${ }^{26}$ As found for the 1990s (Weller, 2000), here, the majority of the new jobs are created are wage employment for workers with medium and high levels of education. As well, in keeping with progress in education systems, only a very small percentage of new employment (around 5\% in the median for 15 countries) corresponds to individuals with 9 or fewer years of schooling.

Comparison of these results with those of the seven countries for which this same calculation was performed for a period in the 1990s (Weller, 2000, p. 157), shows slightly higher labour demand for less educated workers, whose numbers fall in unwaged employment in the median for these seven countries, but rise in the wage worker category. This appears to point to a labour demand that is more balanced by level of education, with less bias towards the most skilled. However, in the median of 15 countries, both wage and unwaged employment expand for individuals with a low level of schooling, albeit slightly more for unwaged. In any case, compared with the results for the $1990 \mathrm{~s}$, when the ratio of job creation for the least skilled in wage employment with respect to unwaged employment was around 0.5 (for seven countries) in the 2000s labour demand for this group was slightly stronger (with a ratio of wage to unwaged employment of 0.8 ), as it was as well for the larger group of countries.

26 The results are also presented for a group of seven countries for which this same information is available for the 1990s (Weller, 2000). Notably, those data cover a period prior to the "lost half-decade" that began in the late 1990s.
In sum, labour demand continued to favour workers with an intermediate or high level of education, although there were also new opportunities for those with little formal education.

To analyse the sectoral characteristics of labour demand, a breakdown was performed using the methodology of Berman, Bound and Griliches (1994) to estimate the contributions of intra- and intersectoral changes both to higher demand for individuals with intermediate and high levels of formal education, and to lower demand for individuals with less formal education. ${ }^{27}$

As is evident in table 5, as in the 1990s, the expansion of wage employment for highly skilled workers was centred in the tertiary sector. Services - the sum of community, social and personal services and financial, real estate and business services - accounted for over half of these new jobs. By contrast with the 1990s, changes in commerce (for example, the large-scale expansion of retail commerce: supermarkets and hypermarkets,

\footnotetext{
27 The breakdown is as follows:

$$
\Delta S=\sum_{i=1}^{n} \Delta A_{i} S_{i}+\sum_{i=1}^{n} \Delta S_{i} A_{i}
$$

for $i=1, \ldots, n$ branches of activity, where:

$\mathrm{S}=$ proportion of workers with a specific level of education in total wage employment.

$\mathrm{S}_{i}=$ proportion of workers with a specific level of education in the branch of activity $i$.

$\mathrm{A}_{i}=$ wage employment in branch $\mathrm{i}$ as a proportion of total wage employment.

The bars show the averages corresponding to the start and end years. The first term on the right of the function thus captures the contributions of changes between branches of activity (i.e. different with respect to the rise in wage employment), while the second term captures the contribution of changes within the branch of activity (i.e. variations in the share of personnel with a specific level of education in wage employment in that branch of activity).
}

TABLE 4

\begin{abstract}
Latin America (median for 7 and 15 countries): composition of net additional employment, by level of education, for wage and non-wage workers, around 2002-2012
\end{abstract}

\begin{tabular}{|c|c|c|c|c|c|}
\hline \multirow{2}{*}{ Group of countries } & \multirow{2}{*}{ Employment category } & \multicolumn{4}{|c|}{ Level of schooling } \\
\hline & & Up to 9 years & $10-12$ years & 13 years or more & Total \\
\hline \multirow{3}{*}{7 countries } & Employed & 3.4 & 46.7 & 44.2 & 100.0 \\
\hline & Waged & 3.3 & 24.7 & 32.6 & 82.4 \\
\hline & Non waged & -5.6 & 13.8 & 7.4 & 17.6 \\
\hline \multirow{3}{*}{15 countries } & Employed & 4.7 & 46.3 & 44.2 & 100.0 \\
\hline & Waged & 3.3 & 26.4 & 32.6 & 77.9 \\
\hline & Non waged & 4.1 & 13.8 & 8.6 & 22.1 \\
\hline
\end{tabular}

Source: prepared by the author, on the basis of data from household surveys conducted in the respective countries.

Note: the seven countries presented separately are Argentina, Brazil, Chile, Colombia, Costa Rica, Peru and the Plurinational State of Bolivia. The group of 15 countries also includes Bolivarian Republic of Venezuela, Dominican Republic, Ecuador, El Salvador, Honduras, Mexico, Panama and Paraguay. 
malls and so on) pushed up demand for highly skilled personnel, and not only because of the expansion of this area of activity (the effect of intersectoral changes), but also because of intrasectoral changes. Conversely, manufacturing made only a weak contribution to demand for highly skilled workers, mainly because of the reduction in the sector's share in total employment. Intrasectoral changes did help to increase demand for skilled workers in manufacturing, although — as shown in the last column of table 5 (a) — the share of highly skilled personnel rose less than in other sectors. In relative terms, what stands out is the upgrading of skills demanded in construction, mining and, again, commerce.
Overall, the rise in the proportion of highly skilled workers within wage earners was due almost entirely to changes within branches of activity. ${ }^{28}$ In several branches, especially in the tertiary sector but also in construction, new jobs were generated on the basis of intersectoral changes, but those additional jobs were largely offset by losses in other branches of activity.

28 This does not necessarily mean production shifts; change within a branch of activity often consists of the substitution of older workers who are retiring with younger workers who have a higher level of formal education.

TABLE 5

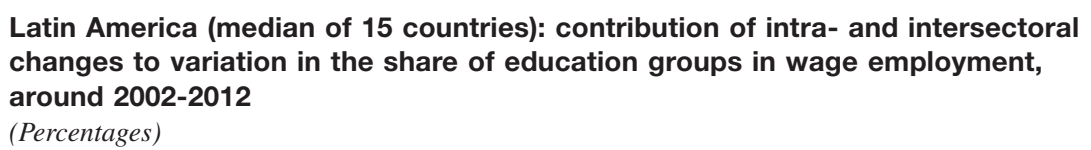

(a) Wage-earners with a high level of education (13 years or more)

\begin{tabular}{|c|c|c|c|c|}
\hline & Intrasectoral changes & Intersectoral changes & Total & Relative increase $^{a}$ \\
\hline Total & 4.09 & 0.20 & 4.29 & 1.00 \\
\hline Agriculture & 0.14 & -0.48 & -0.34 & 1.01 \\
\hline Mining & 0.07 & 0.11 & 0.18 & 1.19 \\
\hline Manufacturing & 0.42 & -0.29 & 0.13 & 0.72 \\
\hline Construction & 0.08 & 0.22 & 0.31 & 1.42 \\
\hline Commerce & 0.75 & 0.27 & 1.02 & 1.18 \\
\hline Transport and communications & 0.26 & 0.16 & 0.42 & 1.14 \\
\hline Services & 2.37 & 0.22 & 2.59 & 0.94 \\
\hline
\end{tabular}

(b) Wage-earners with an intermediate level of education (10-12 years)

\begin{tabular}{|c|c|c|c|}
\hline & Intrasectoral changes & Intersectoral changes & Total \\
\hline Total & 3.56 & 0.84 & 4.38 \\
\hline Agriculture & 0.41 & -0.03 & 0.37 \\
\hline Manufacturing & 1.18 & -0.69 & 0.49 \\
\hline Construction & 0.54 & 0.33 & 0.88 \\
\hline Commerce & 0.80 & 0.89 & 1.69 \\
\hline Transport and communications & 0.43 & 0.19 & 0.62 \\
\hline Services & 0.20 & 0.06 & 0.25 \\
\hline
\end{tabular}

(c) Wage-earners with a low level of education (up to 9 years)

\begin{tabular}{|c|c|c|c|}
\hline & Intrasectoral changes & Intersectoral changes & Total \\
\hline Total & -7.56 & -1.01 & -8.58 \\
\hline Agriculture & -0.61 & -1.74 & -2.34 \\
\hline Manufacturing & -1.57 & -1.24 & -2.81 \\
\hline Construction & -0.66 & 0.77 & 0.11 \\
\hline Commerce & -1.50 & 0.84 & -0.66 \\
\hline Services & -2.49 & 0.03 & -2.46 \\
\hline
\end{tabular}

Source: prepared by the author, on the basis of data from household surveys conducted in the respective countries.

a Ratio between percentage growth of the education group in the particular branch of activity, and the percentage growth of the education group across all wage-earners.

Note: The countries covered are: Argentina, Bolivarian Republic of Venezuela, Brazil, Chile, Colombia, Costa Rica, Dominican Republic, Ecuador, El Salvador, Honduras, Mexico, Panama, Paraguay, Peru and the Plurinational State of Bolivia. 
The rise in the proportion of workers with an intermediate level of formal education was also due mainly to intrasectoral changes (and, thus, part of the generalized rise in education level). However, intersectoral changes had a much stronger impact for this group than for more highly educated wage earners. In this respect, labour demand was notably strong from commerce and, to a much lesser degree, construction, transport and communications. Commerce also stands out for a large rise in workers with intermediate levels of education driven by intrasectoral changes, which underscores the impact of upgrading as noted earlier in relation to more skilled workers. Manufacturing also shows clear signs of upgrading of personnel structure, with sharp increases in workers with intermediate and (as already seen) high levels of education.

The contraction of employment of workers with low levels of formal education was also concentrated in changes within branches of activity, pushed along in part by upgrading of the educational structure in services, manufacturing and commerce. However, intersectoral shifts also played a role in this process, especially a reduction in employment in agriculture and manufacturing. The expansion of commerce and, in particular, construction, also produced jobs for workers with a low level of formal education.

The concentration of economic growth in the tertiary sector in 2003-2012 did not, then, reduce demand for highly qualified workers. As in the 1990s, such demand was in fact concentrated in the tertiary sector (Weller, 2000). In commerce, specifically, there are signs of upgrading driving demand for skilled workers. ${ }^{29}$ As well, and unlike in previous years, in some cases shifts within - and sometimes between - sectors increased demand for workers with intermediate education and, to a lesser extent, with little formal education. Again, these processes occurred especially in the tertiary sector, although internal shifts also favoured expansion of employment for the group with intermediate education in manufacturing and agriculture. ${ }^{30}$ This partial change in labour demand patterns appears to have benefited

\footnotetext{
29 This result contradicts the finding of the World Bank (2012) that the strengthening of non-tradable sectors led to a fall in demand for skilled labour.

30 Klasen, Otter and Villalobos Barría (2012) found that the natural resources boom in the mid-2000s had a beneficial distributive effect in rural areas in Honduras, by improving the income of agricultural workers. There is also anecdotal evidence from several countries to the effect that reduced labour supply has led to income gains in the agricultural sector.
}

relatively less skilled workers (at least in terms of income) and helped to close wage gaps.

The shift in employment towards medium- and high-productivity segments also benefited average income in the low-productivity segments. As noted earlier, employment in these segments is heterogeneous. In countries with lower per capita GDP and thus a smaller proportion of wage-earners among the employed, a large share of own-account employment reflects supply pressure (Weller and Kaldewei, 2013, pp. 35-39). In these countries, per the theoretical arguments outlined in section IV, average labour income from own-account work is lower than in countries with a smaller proportion of own-account workers (where many of them choose to work independently in search of advantages) (Weller, 2012, p. 35).

Accordingly, a relative reduction in employment in low-productivity segments should also help to drive intrasectoral changes by lessening supply pressure and, specifically, should increase average income in these segments. Between 1990 and 2000-2002, the average income of wage workers (excluding professional and technical workers) in firms with five or more employees remained constant in poverty line terms, while the income of own-account workers (again excluding professional and technical workers) dropped by 0.6 of a poverty line. By contrast, between 2000-2002 and 2009-2010 the income of both groups rose (on average) by 0.4 and 0.6 of a poverty line, respectively. ${ }^{31}$

In sum, better economic conditions favoured the income of those employed at the base of the labour income scale, mainly because of two related mechanisms: stronger labour demand (especially in tertiary sector activities) for workers with low and intermediate levels of education, and declining supply pressure on lowproductivity segments.

\section{Labour institutions and employment characteristics}

Apart from economic and production context, labour institutions have the greatest impact on the evolution and characteristics of employment. Recent changes in labour institutions have helped bring about improvements, especially in terms employment quality wage gaps.

In the first decade of this century the prevailing views on labour institutions shifted in many countries. The reforms of the 1990s emphasized expanding the

\footnotetext{
31 Author's calculations on the basis of ECLAC (2012).
} 
range of hiring modalities, especially by using fixed-term contracts instead of the traditional indefinite contract, extending the use of trial periods and facilitating outsourcing mechanisms. Reforms also reduced the cost of dismissal, mainly by broadening the definition of fair dismissal and introducing unemployment insurance systems based on individual accounts (Vega Ruiz, 2005).

Generally speaking, and often as part of macroeconomic stabilization packages, real minimum wages fell sharply in the 1980s, then stagnated in the 1990s. In many cases labour inspection practices also weakened, amid broader strategies to reduce the role and size of the State. As a result, in many cases the gap between legal provisions and the reality at work tended to widen (Bensusán, 2006).

At the same time, the proportion of employment in medium- and high-productivity segments fell (owing to low rates of economic growth, a sharp fall in the proportion of public-sector employment and, at least temporarily, a drop in wage employment-GDP elasticity), which led to "de facto flexibilization". It also sapped the power of the trade unions.

The poor results of the reforms of the 1980s and 1990s and the various crises that broke out in Latin America and the Caribbean after the mid-1990s undermined the credibility of deregulation-based labour policy as a tool for job creation. Against this backdrop, in the 2000s new political proposals emerged in the region under the premise that the response to globalization should not be a one-fits-all approach to production restructuring and economic and labour policy (Fraile, 2009; Weller, 2009; Lee and McCann, 2011). At the same time, radical deregulation began to be treated with increasing caution in the international debate (IDB, 2003; Freeman, 2005). In Latin America, scepticism regarding deregulation is also driven by the fact that large-scale liberalizing reforms were considered to have had little impact on economic growth (IDB, 1997), and that the expectations of formal jobs creation attached to the reforms were not fulfilled.

In the 2000s, trade union organization improved in some countries and the decline in organized labour eased or reversed. ${ }^{32}$ In this scenario, collective bargaining began to cover a slightly wider range of issues and new groups of workers, such as seasonal and domestic workers. In some cases, outsourcing was regulated after evidence that this tool tended to be abused, and employment

\footnotetext{
32 See ILO (2009) for an illustration of the decline in labour organization between 1989 and 2005 .
}

conditions for domestic workers were brought into line with those for the general workforce.

Several countries addressed the gap between legislation in place and actual compliance by boosting resources for labour inspection. Many also developed schemes to encourage business and labour formalization, specifically in microenterprises and SMEs (ILO, 2014). Since informality is determined both by aspects of the production structure and by institutional factors, formalization policies also help to reduce labour market segmentation. In particular, formalization of contractual relations is crucial for employment quality, because the evidence shows that a formal contract of employment is often the key that unlocks other benefits that come with good-quality jobs (Weller and Roethlisberger, 2011; ECLAC/ILO/FAO, 2012).

A number of countries adopted reforms with a protective slant regarding individual labour relations, for example by reducing weekly working hours, increasing compensation for unfair dismissal, restricting the use of overtime or increasing overtime pay, and extending prenatal and postnatal leave.

At the same some, some countries strengthened unemployment insurance schemes or created new models (and a number of countries are in the process of doing so) to broaden systems to protect workers in the context of more volatile markets. Many countries have taken a more active stance on minimum wage policy, as well. ${ }^{33}$ As in the 1990s, in Mexico the drop in the minimum wage was identified as having contributed significantly to broadening income gaps (Cortez, 2001; Bosch and Manacorda, 2010). Concerning the recent period, Cornia (2014), Keifman and Maurizio (2012), and ECLAC (2014c) all found that minimum wage gains and increased formality - or the combination of both-have been important factors in narrowing in gaps in several countries.

In short, unlike during preceding decades, in the recent period stronger measures were taken to strengthen workers' individual and collective rights in respect of the twofold purpose of labour institutions mentioned earlier, supported by measures such as business and labour formalization policies, albeit generally without leaving aside the aim of labour market efficiency.

\footnotetext{
${ }^{33}$ In the median for 20 countries, the real minimum wage shows no change in 1990-2003, but increased by $2.0 \%$ in 2003-2012. If the changes are weighted by the working-age population, the annual increase for the recent period was $4.4 \%$ (author's calculation on the basis of official data from the countries).
} 


\section{$\mathrm{V}$}

\section{Conclusions}

In the period 2003-2012, the performance of the labour markets of Latin America and the Caribbean represented a departure from previous patterns in several aspects. In particular, the open unemployment rate fell noticeably thanks to a rise in employment levels, employment quality indicators improved in a context of labour formalization, and income gaps between more and less skilled workers narrowed.

To understand the factors influencing this performance, this article proposed analysing the behaviour of the economic and production context (economic growth, labour productivity trends and changes in structural heterogeneity) and of labour institutions. Review of these factors for the decade considered shows that the combination of the two factors shaped the three stylized facts characterizing recent labour performance. Relatively high economic growth stimulated labour demand, which boosted employment generation, especially in mediumand high-productivity segments, facilitating increased formality and higher labour income. The characteristics of labour demand, centred on non-tradable sectors (the tertiary sector and construction), set the patterns for employment generation. Intra- and intersectoral shifts led to rises in productivity, related —in several branches of activity, such as commerce and transport, storage and communications - to upgrading of the occupational structure, which helped to improve employment quality. Labour demand characteristics improved opportunities for workers with low and intermediate levels of education, as well, which helped to narrow income gaps. Institutional changes also contributed to narrowing these gaps, to employment formalization and to improvements in employment quality indicators. Strong employment generation was a key factor in bringing down poverty rates, as was the reduction in income gaps for lessening inequality at the household level.

Despite the progress noted, which reversed previous trends, labour markets in the region continued to show severe weaknesses, such as high levels of informality, large productivity gaps, a high percentage of poor and unprotected workers, low levels of labour market participation by women, sharp labour inequalities between men and women both within and outside labour markets, discrimination against various groups of workers, poor employment quality indicators, and low rates of continuous training, trade union membership and collective bargaining. Obviously, recent advances notwithstanding, the challenges remain considerable.

A number of factors threaten to at least slow the pace of labour improvements in the near future. First, amid slower global economic growth than in the recent past, the outlook for regional growth is less promising amid slacker external demand (ECLAC, 2014b). At the same time, in many countries domestic demand growth (driven chiefly by household consumption) is slowing owing to factors such as the end of the terms-of-trade gain (which slows the increase in disposable national income), the end of a period of exchange-rate appreciation and high levels of household indebtedness. At the regional level, employment generation was already weak by 2013 , both in absolute terms and in relation to that year's economic growth (ECLAC, 2014a).

From the policy standpoint, the tendency in many countries to focus formalization efforts on incentives and more stringent oversight could start to yield diminishing returns. This is because many firms and workers with the production potential to assume the necessary costs have already done so, while other firms and workers still operating in informal conditions are labour-supply driven and their productivity is too low to support full formalization. It may, then, be time to rethink instruments for promoting development, especially of microenterprises and SMEs. It is also important to strengthen the virtuous cycle between labour productivity gains and employment quality. Key steps to this end are improving education, professional training and capacity-building, and strengthening the voice of workers by expanding organized labour and collective bargaining. 


\section{Bibliography}

Akerlof, George A. and Janet Louise Yellen (1986), Efficiency Wage Models of the Labor Market, New York, Cambridge University Press.

Azevedo, João Pedro and others (2013), "Is labor income responsible for poverty reduction? A decomposition approach", Policy Research Working Papers, No. 6414, Washington, D.C., World Bank.

Azevedo, João Pedro, Gabriela Inchauste and Viviane Sanfelice (2013), "Decomposing the recent inequality decline in Latin America", Policy Research Working Papers, No. 6715, Washington, D.C., World Bank.

Ball, Laurence M., Nicolás de Roux and Marc Hofstetter (2011), "Unemployment in Latin America and the Caribbean", NBER Working Paper, No. 17274, Cambridge, Massachusetts, National Bureau of Economic Research.

Bensusán, Graciela (2008), "Regulaciones laborales, calidad de los empleos y modelos de inspección: México en el contexto latinoamericano" (LC/MEX/L.861), Mexico City, ECLAC Subregional Headquarters in Mexico.

(coord.) (2006), Diseño legal y desempeño real: Instituciones laborales en América Latina, Mexico City, Chamber of Deputies/Metropolitan Autonomous University.

Berg, Janine and David Kucera (2008), "Labour institutions in the developing world: historical and theoretical perspectives", In Defence of Labour Market Institutions. Cultivating Justice in the Developing World, Janine Berg and David Kucera (eds.), Basingstoke, Palgrave MacMillan.

Berman, Eli, John Bound and Zvi Griliches (1994), "Changes in the demand for skilled labor within U.S. manfacturing: evidence from the Annual Survey of Manufactures", The Quarterly Journal of Economics, vol. 109, No. 2, Oxford University Press, May.

Bosch, Mariano, M. Belén Cobacho and Carmen Pagés (2012), "Taking stock of nine years of implementation of Seguro Popular in Mexico", Technical Notes, No. IDB-TN-442, Washington, D.C., Inter-American Development Bank.

Bosch, Mariano and Marco Manacorda (2010), "Minimum wages and earnings inequality in urban Mexico", American Economic Journal: Applied Economics, vol. 2, No. 4, Nashville, Tennessee, American Economic Association.

Cornia, Giovanni Andrea (2014), "Income inequality in Latin America. Recent decline and prospects for its further reduction", Macroeconomía del Desarrollo series, No. 149 (LC/L.3847), Santiago, Chile, Economic Commission for Latin America and the Caribbean (ECLAC).

Cortez, Willy W. (2001), "What is behind increasing wage inequality in Mexico?", World Development, vol. 29, No. 11, Amsterdam, Elsevier.

Cruces, Guillermo, Carolina García Domenech and Leonardo Gasparini (2012), "Inequality in education: evidence for Latin America", Working Paper, No. 135, Center for Distributive, Labor and Social Studies (CEDLAS).

ECLAC (Economic Commission for Latin America and the Caribbean) (2014a), Preliminary Overview of the Economies of Latin America and the Caribbean, 2013 (LC/G.2581-P), Santiago, Chile. United Nations publication, Sales No. E.14.II.G.2.

(2014b), Economic Survey of Latin America and the Caribbean 2014 (LC/G.2619-P), Santiago, Chile. United Nations publication, Sales No. E.14.II.G.3.

(2014c), Compacts for Equality: Towards a Sustainable Future (LC/G.2586(SES.35/3)), Santiago, Chile.

(2013), Social Panorama of Latin America 2013 (LC/G.2580), Santiago, Chile. United Nations publication, Sales No. E.14.II.G.6.

(2012), Social Panorama of Latin America 2011 (LC/ G.2514-P), Santiago, Chile. United Nations publication, Sales No. E.12.II.G.6.
(2010), Time for equality: closing gaps, opening trails (LC/G.2432(SES.33/3)), Santiago, Chile.

(2007), "Progreso técnico y cambio estructural en América Latina", Project Document, No. 136 (LC/W.136), Santiago, Chile.

(various years), Economic Survey of Latin America and the Caribbean, Santiago, Chile.

ECLAC/ILO (Economic Commission for Latin America and the Caribbean/International Labour Organization) (2013), "Youth employment: crisis and recovery", The Employment Situation in Latin America and the Caribbean, No. 7, Santiago, Chile, October.

(2012), "Labour productivity and distribution issues", The Employment Situation in Latin America and the Caribbean, No. 6, Santiago, Chile, May.

ECLAC/ILO/FAO (Economic Commission for Latin America and the Caribbean/International Labour Organization/Food and Agriculture Organization of the United Nations) (2012), Labour Market Policies and Rural Development in Latin America, Food and Agriculture Organization of the United Nations (FAO), Rome.

Eichhorst, Werner, Michael Feil and Christoph Braun (2008), "What have we learned? Assessing labor market institutions and indicators", IZA Discussion Papers, No. 3470, Bonn, Institute for the Study of Labour (IZA).

Fields, Gary (2004), A Guide to Multisector Labor Market Models, Washington, D.C., November.

Fraile, Lydia (2009), "Lessons from Latin America's neo-liberal experiment: An overview of labour and social policies since the 1980", International Labour Review, vol. 128, No. 3.

Freeman, Richard B. (2005), "Labor market institutions without blinders: the debate over flexibility and labor market performance", NBER Working Paper, No. 11286, Cambridge, Massachusetts, National Bureau of Economic Research.

Gasparini, Leonardo and others (2011), "Educational upgrading and returns to skills in Latin America. Evidence from a supplydemand framework, 1990-2010", Policy Research Working Paper, No. 5921, Washington, D.C., World Bank.

IDB (Inter-American Development Bank) (2003), Good Jobs Wanted. Labor Markets in Latin America, Washington, D.C.

(1997), Economic and Social Progress in Latin America. 1997 Report, Washington, D.C.

ILO (International Labour Organization) (2014), Recent Experiences of Formalization in Latin America and the Caribbean, Lima, ILO Regional Office for Latin America and the Caribbean.

(2013), "Key Indicators of the Labour Market (kilm)", eigth edition [online] http://www.ilo.org/empelm/what/ WCMS_114240/lang--en/index.htm.

(2009), World of Work Report 2008. Income Inequalities in the Age of Financial Globalization, Geneva.

(various years), Panorama Laboral de América Latina y el Caribe, Lima, Regional Office for Latin America and the Caribbean.

Infante, Ricardo (ed.) (2011), "El desarrollo inclusivo en América Latina y el Caribe. Ensayos sobre políticas de convergencia productiva para la igualdad", Libros de la CEPAL, No. 112 (LC/G.2500-P), Santiago, Chile, Economic Commission for Latin America and the Caribbean (ECLAC). United Nations publication, Sales No. S.11.II.G.56.

Kacef, Osvaldo and Rafael López-Monti (2010), "Latin America, from boom to crisis: macroeconomic policy challenges", CEPAL Review, No. 100 (LC/G.2442-P), Santiago, Chile.

Keifman, Saúl N. and Roxana Maurizio (2012), "Changes in labour market conditions and policies. Their impact on wage inequality during the last decade", WIDER Working Papers, No. 2012/14, Helsinki, United Nations University/World Institute for Development Economics Research. 
Klasen, Stephan, Thomas Otter and Carlos Villalobos Barría (2012), "The dynamics of inequality change in a highly dualistic economy: Honduras, 1991-2007", WIDER Working Papers, No. 2012/17, Helsinki, United Nations University/World Institute for Development Economics Research.

Lee, Sangheon and Deirdre McCann (2011), Regulating for Decent Work: New Directions in Labour Market Regulation, Geneva, International Labour Organization (ILO).

López-Calva, Luis F. and Nora Lustig (eds.) (2010), Declining Inequality in Latin America. A Decade of Progress?, Washington, D.C., Brookings Institution Press.

McMillan, Margaret S. and Dani Rodrik (2011), "Globalization, structural change and productivity growth", NBER Working Paper, No. 17143, Cambridge, Massachusetts, National Bureau of Economic Research.

Ocampo, José Antonio, Codrina Rada and Lance Taylor (2009), Growth and Policy in Developing Countries: A Structuralist Approach, New York, Columbia University Press.

Pagés, Carmen, Gaëlle Pierre and Stefano Scarpetta (2009), Job Creation in Latin America and the Caribbean. Recent Trends and Policy Challenges, Washington, D.C., World Bank.

Perry, Guillermo E. and others (2007), Informality: Exit and Exclusion, Washington, D.C., World Bank.

Rodrik, Dani (2013), "The past, present, and future of economic growth", Working Paper, No. 1, Global Citizen Foundation, June.

Ros, Jaime (2011), "La productividad y el desarrollo en América Latina: Dos interpretaciones", Economía UNAM, vol. 8, No. 23, Mexico City, National Autonomous University of Mexico.

Tokman, Víctor (1987), "El sector informal: Quince años después", Documento de Trabajo, No. 316, Santiago, Chile, Regional
Employment Programme for Latin America and the Caribbean (PREALC).

Vega Ruiz, María Luz (2005), La reforma laboral en América Latina: 15 años después, Lima, ILo Regional Office for Latin America and the Caribbean.

Weller, Jürgen (2012), "Crecimiento, empleo y distribución de ingresos en América Latina”, Macroeconomía del Desarrollo series, No. 122 (LC/L.3516), Santiago, Chile, Economic Commission for Latin America and the Caribbean (ECLAC).

(2009), "Avances y retos para el perfeccionamiento de la institucionalidad laboral en América Latina”, El nиеvo escenario laboral latinoamericano. Regulación, protección y políticas activas en los mercados de trabajo, Jürgen Weller (ed.), Buenos Aires, Siglo XXI Editores.

(2000), Reformas económicas, crecimiento y empleo: Los mercados de trabajo en América Latina, Santiago de Chile, Economic Commission for Latin America and the Caribbean (ECLAC)/Fondo de Cultura Económica.

Weller, Jürgen and Cornelia Kaldewei (2013), "Empleo, crecimiento sostenible e igualdad", Macroeconomía del Desarrollo series, No. 145 (LC/L.3743), Santiago, Chile, Economic Commission for Latin America and the Caribbean (ECLAC).

Weller, Jürgen and Claudia Roethlisberger (2011), "La calidad del empleo en América Latina", Macroeconomía del Desarrollo series, No. 110 (LC/L.3320-P), Santiago de Chile, Economic Commission for Latin America and the Caribbean (ECLAC). United Nations publication, Sales No. S.11.II.G.39.

World Bank (2012), The Labor Market Story Behind Latin America's Transformation, Washington, D.C. 